\title{
Spatial distribution of the amazon river prawn Macrobrachium Amazonicum (Heller, 1862) (Decapoda, Caridea, Palaemonidae) in two perennial creeks of an estuary on the northern coast of Brazil (Guajará Bay, Belém, Pará)
}

\author{
Bentes, BS. *, Martinelli, JM., Souza, LS., Cavalcante, DV., Almeida, MC. and Isaac, VJ. \\ Instituto de Estudos Costeiros - IECOS, Universidade Federal do Pará - UFPA, \\ Alameda Leandro Ribeiro, s/n, CEP 68600-000, Bragança, Pará, Brazil \\ Laboratório de Biologia Pesqueira e Manejo de Recursos Aquáticos, \\ Av. Perimetral, 2651, CEP 66077-530, Belém, Pará, Brazil \\ *e-mail: bianca@ufpa.br
}

Received August 16, 2010 - Accepted October 19, 2010 - Distributed November 30, 2011

(With 5 figures)

\begin{abstract}
Macrobrachium amazonicum is the most frequently consumed freshwater crustacean by river communities of the Amazon. Despite its relative abundance and vast knowledge on the species from data on cultivated specimens, little is known regarding its biology in the natural environment, especially its use of creeks that are strongly influenced by the tide. Specimens of Macrobrachium amazonicum were collected in September 2006 (dry season) and March 2007 (rainy season) from two perennial creeks of the Guajará Bay in the state of Pará (northern Brazil), using traps similar to the matapis used by local fishermen to identify the spatial distribution of the species. Shrimps of all sizes use the tidal creeks in both seasons, including for breeding purposes. The greatest abundance of the species occurred in headwater areas and in the dry season. It is suggested that abundant allochthonous organic matter and the preference for protected areas may explain the abundance and breeding activity of this species in the headwaters of the creeks.
\end{abstract}

Keywords: creek, Macrobrachium, Amazon River prawn, estuary.

\section{Distribuição espacial do camarão-da-amazônia - Macrobrachium Amazonicum (Heller, 1862) (Decapoda, Caridea, Palaemonidae) em dois canais perenes de um estuário da costa norte do Brasil (Baía do Guajará - Belém, Pará, Brasil)}

\section{Resumo}

Macrobrachium amazonicum é o crustáceo dulcícola mais frequentemente consumido pelas populações ribeirinhas da Amazônia. Entretanto, apesar de sua relativa abundância e vasto conhecimento da espécie a partir de dados de cultivo, pouco se conhece sobre sua biologia no ambiente natural, especialmente quanto à forma de utilização de canais fortemente influenciados pelas marés. Amostras desse camarão foram coletadas em setembro/06 (período seco) e março/07 (período chuvoso), em dois canais perenes da Baía do Guajará, Pará, utilizando armadilhas (matapis) como as utilizadas pelos pescadores locais para identificar a distribuição espacial dos organismos. Os canais de maré são utilizados por camarões de todos os tamanhos nas duas estações do ano, inclusive para a reprodução. A maior abundância de indivíduos da espécie foi encontrada no período seco, nas áreas a montante dos canais . Postula-se que a abundante matéria orgânica alóctone e a busca de locais protegidos podem ser os fatores que explicam a concentração da abundância e da atividade reprodutiva nas áreas a montante dos canais.

Palavra-chave: canais de maré, Macrobrachium, camarão-da-amazônia, estuário. 


\section{Introduction}

Macrobrachium shrimps are widely distributed in both tropical and subtropical regions. In South America, this genus is found in rivers that drain into the Atlantic (New, 1980; Romero, 1982) and inhabits either brackish or freshwater environments, from estuaries to rivers of all orders and lateral streams, including grassland lakes (Magalhães, 1985; Odinetz-Collart, 1991). Species of Macrobrachium have continuous breeding, which is reported to be more intensive in the rainy season in the Central Amazon (Odinetz-Collart, 1991). While there are as yet no records on the sites these species seek for breeding purposes, they are known to exhibit differentiated breeding strategies adapted to the most diverse environments. For instance, females may produce a large amount of small eggs which have several larval stages which are planctonic (Magalhães and Walker, 1988).

The Amazon River shrimp, Macrobrachium amazonicum, exhibits different breeding patterns throughout the Amazon River and its tributaries. The regulation of its reproductive cycle by gonad maturation control mechanisms may or may not be associated to external body changes, such as the male morphotypes defined by Moraes-Riodades and Valenti (2004). Such differences seem to be related to variations in the discharge of the rivers and primary production in these sites (Odinetz-Collart and Magalhães, 1994).

The Amazon River shrimp is widely caught and commercialised in the region of the islands near Belém and it serves as a major (and sometimes only) source of animal protein for local residents. Despite its economic value and cultural importance as an ingredient in regional recipes, management of the species is nearly non-existent due, among other reasons, to the gaps in the knowledge regarding its biology and fishing efforts in the natural environment.

Studies on the horizontal distribution of the Amazon River shrimp and its reproductive activity are mainly limited to riverbeds (Rodríguez, 1982; Valenti et al., 1989; Odinetz-Collart, 1991; Odinetz-Collart and Moreira, 1993; Silva et al., 2002; Vieira, 2003; Santos et al., 2006; Silva et al., 2007; Sampaio et al., 2007; Sampaio et al., 2008; and others). However, the species is often caught in tidal creeks that may or may not connect directly to the rivers. Creeks are defined here as bodies of water that communicate with rivers or streams of the same river, locally denominated 'igarapés' . The creeks of the islands of Guajará Bay near the city of Belém are perennial and are influenced by the tide. In some cases, these creeks make no connections to other bodies of water and the extremity is formed by a narrow expanse of water that is normally non-navigable, even at high tide. The species M. amazonicum is caught in these narrow creeks, but the function of these environments for the species is unknown.

The aim of the present study was to characterise the horizontal distribution of M. amazonicum in tidal creeks in Guajará Bay (northern Brazil).

\section{Materials and Methods}

Guajará Bay (Figure 1) is located to the west of the city of Belém (state of Pará, Brazil). The Guamá and Moju Rivers flows into this bay, along with a substantial number of small streams influenced by the tide. The bay is narrow and elongated, compressed between the mainland and the islands of Combu, Onças, Arapiranga and Cotijuba. It connects to Marajó Bay and, more to the north, to Mosqueiro Island and the district of Outeiro pertaining to the city of Belém (Moreira, 1966) (Figure 1).

High turbidity is one of the main characteristics of the Guajarino estuary due to the large amount of suspended matter, giving the water a muddy, greenish-yellow appearance, which hinders the penetration of light. Average rainfall is $2831 \mathrm{~mm}$.year ${ }^{-1}$, ranging from $127.43 \mathrm{~mm} . \mathrm{month}^{-1}$ in the drier season to $309.62 \mathrm{~mm} . \mathrm{month}^{-1}$ in the rainy season (ANA, 2007). In the drier season, the waters of the lower course of the estuary become brackish (Cordeiro, 1987) due to the influence of the semi-diurnal oceanic tides.

Specimens of $M$. amazonicum were caught in two perennial creeks of Guajará Bay: Tamanduaquara Creek (Figure 1c), located on Mosqueiro Island, to the north of the bay; and Combu Creek, located on Combu island, to the south of Guajará Bay (Figure 1d). Both creeks are approximately $4 \mathrm{~km}$ in length, are navigable and are located near the city of Belém, which is the largest urban centre in the region. However, the creeks have not yet been greatly affected by human activities and both are considered relatively unpolluted (Viana et al., 2010).

Specimens of M. amazonicum were caught with the aid of traps known locally as matapis, which are the main gear used by local fishermen targeting this resource. The traps were made with thin strips of the 'juba' (Astrocaryum spp and Atrix spp.) or 'jupati' (Raphia vinifer) palms, tied with a strip of vine and forming a cylindrical trap closed at one end in the form of a funnel. This trap can also be made with polyethylene bottles (PET), in which the ends are closed using the upper parts of the bottle (Figure 2a).

Four sets of six traps were tied to the banks of each creek [two large (L), two medium-sized (M) and two small (S) traps]. $\mathrm{L}$ and $\mathrm{M}$ traps were made with strips of wood from palm plants and $\mathrm{S}$ traps were made from PET bottles. The sets of traps were arranged alternately on the right and left bank of each creek at a distance of approximately $1 \mathrm{~km}$ between sites from the mouth to the headwater of the creek (Site A, B, C, D), totaling 24 traps distributed along $4 \mathrm{~km}$ of each creek (Figure 2b). S and M traps were baited with a meal made from babassu (Orbignya speciosa) wrapped in aninga leaves (Montrichardia linifera). L traps were baited with pieces of fish.

Sampling was carried out concomitantly in both tidal creeks in September 2006 (dry season) and March 2007 (rainy season) during one tide cycle (12 hours), beginning and ending with the low tide under a waning moon 48 hours prior to the new moon. Water temperature and salinity were recorded for each site in each study period. 
(a)
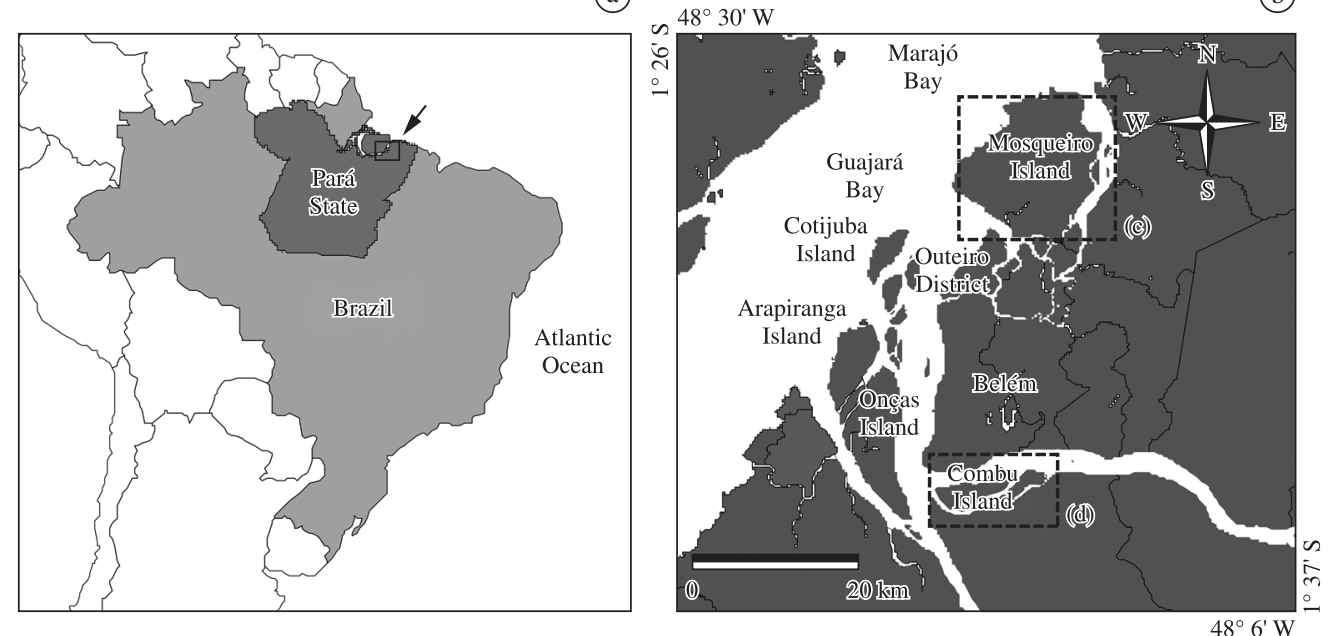

(c)
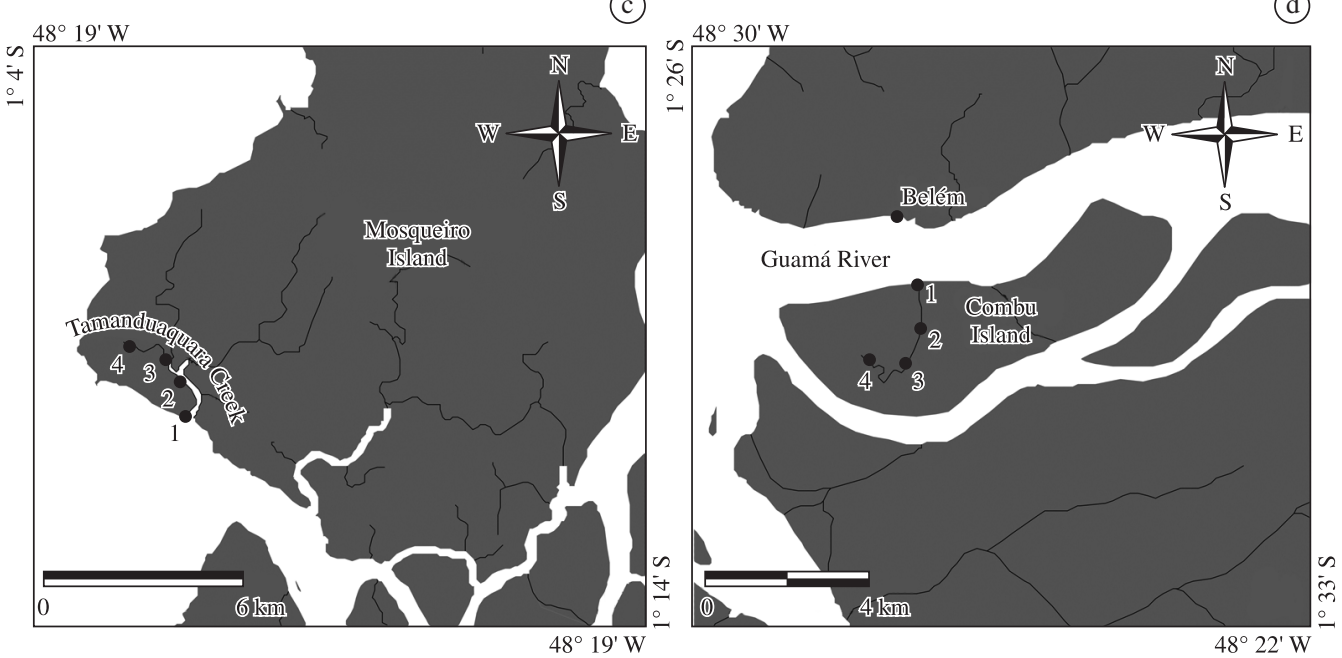

Figure 1. Study region highlighting main islands in b) Guajará Bay, c) Tamanduaquara Creek and d) Combu Creek; regions highlighted with dashed line in b) seen in greater detail in c) and d).

At the end of the 12 hours period, the traps were removed and the shrimps caught were placed in labeled plastic bags and transported to the laboratory in thermal chests with crushed ice. Abundance was estimated by the estimated catch per unit of effort. Total length ( $\mathrm{Lt}$ - measured in $\mathrm{mm}$ from the anterior portion of the rostrum to the posterior portion of the telson), carapace length ( $\mathrm{Lcr}$ - measured in $\mathrm{mm}$ from the posterior portion of the orbit to the posterior extremity of the carapace) and total weight ( $\mathrm{W}$ in $\mathrm{g}$ ) were recorded. Sex was determined by an examination of the endopodite morphology of the second pair of pleopods, as proposed by Ismael and New (2000). Stages of morphological gonad maturation were identified macroscopically. Five stages of maturation were recorded for females (I) immature; II) maturing; III) mature; IV)with eggs in pleopods; and V) spawned), based on colouring, size, location and appearance of the ovary observed by transparent carapace adapted by Carvalho and Pereira (1981) and Chaves and Magalhães (1983). Two stages of maturation were recorded for males (I) immature and II) mature), based on colouring and size of the testes descriptions adapted from Ribeiro-Filho (1988).

Absolute abundance in the samples was considered proportional to the density of the creek. The linear regression equation was established $(\mathrm{Y}=\mathrm{bX}+\mathrm{a})$ between $\mathrm{Lcr}$ and $\mathrm{Lt}$ and the coefficient of determination $\left(\mathrm{r}^{2}\right)$ was subsequently calculated. Mean abundance, length and weight were compared separately between seasons, sampling sites and maturation stages using either analysis of variance (ANOVA; $\mathrm{a}=0.05$ ) or the Kruskal-Wallis test as the data did not present normal distribution, even after undergoing transformations. Bar graphs were constructed for the visual comparison of the absolute abundance distribution of gonad maturation stages between seasons and collection sites. The sex proportion was determined per season and collection 

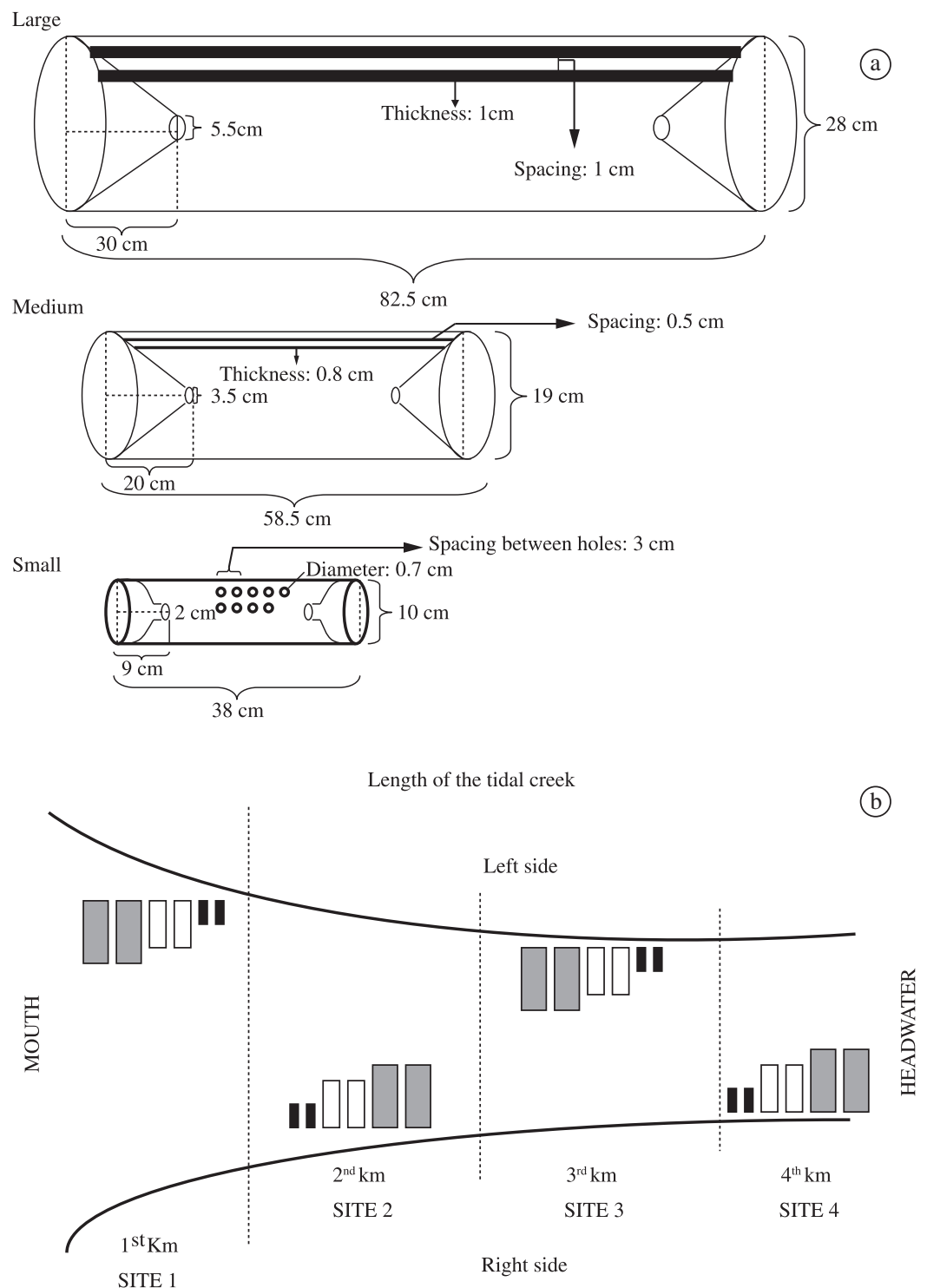

$\square$ Matapi L $\square$ Matapi M $\square$ Matapi S

Figure 2. a) Schematic of sampling units used in two creeks of Guajará Bay, Pará, Brazil; large (L) and medium-size (M) traps made with wooden strips and small (S) traps made with polyethylene bottles; b) schematic of positioning of traps in Combu and Tamanduaquara Creeks in Guajará Bay; although represented side by side, the traps were actually arranged randomly within the area corresponding to each sampling site.

site and compared between seasons and among sites using the chi-square test $\left(\mathrm{c}^{2} ; \mathrm{a}=0.05\right)$ according to Zar (1996).

\section{Results}

The Tamanduaquara and Combu Creeks are representative of those frequently found in the Guajará Bay, with a gradual narrowing in width at greater distances from the mouth (approximately $10 \mathrm{~m}$ at the mouth and less than $2 \mathrm{~m}$ at the headwaters). The breadth of the creek ranges from three to $10 \mathrm{~m}$ in the dry and rainy season, respectively (above the high tide line). These creeks are shallow, ranging from a few centimetres to about four $\mathrm{m}$ in depth, and have a muddy bottom. Water temperature ranges from 25 to $28^{\circ} \mathrm{C}$ in the dry and rainy season, respectively. Salinity ranges from 8 to $0 \%$ in the dry and rainy season, respectively.

A total of 1019 shrimps were caught, among which M. amazonicum accounted for $95 \%$. The other $5 \%$ were made up of Macrobrachium surinamicum, M. carcinus, $M$. acanthurus and $M$. rosenbergii.

Specimens of $M$. amazonicum occurred throughout the length of both creeks and in both collection periods. 
Mean abundance of individuals (with sexes pooled) was statistically different between periods (September $>$ March; $\left.\mathrm{F}_{1}=724.6 ; \mathrm{p}<0.01\right)$ and sampling sites $(\mathrm{D}>\mathrm{C}>\mathrm{B}>\mathrm{A}$; $\left.\mathrm{F}_{3}=145.1 ; \mathrm{p}<0.01\right)$, indicating that the species seeks more distant sites from the mouth of the creek. There were no differences in abundance with regard to sex $\left(F_{1}=0.02\right.$; $\mathrm{p}>0.05)$. There were also no differences in abundance between creeks $\left(F_{1}=0.22 ; p>0.05\right)$, demonstrating that both bodies of water offer similar conditions for explaining the distribution of $M$. amazonicum.

The individuals caught had a carapace length ranging from $4.22 \mathrm{~mm}$ to $29 \mathrm{~mm}$ and weight ranging from $0.04 \mathrm{~g}$ to $7.25 \mathrm{~g}$. Both the smallest and largest specimens were caught in September (Table 1). The linear regression equation between $\mathrm{Lcr}$ and $\mathrm{Lt}$ was $\mathrm{Lt}=9.3944+4.0223$. Lcr $\left(R^{2}=0.88\right)$ for pooled sexes, thereby establishing positive allometric growth $(\mathrm{b}>1)$. General mean carapace length was $12 \mathrm{~mm}$ for pooled sexes, $12.7 \mathrm{~mm}$ for females and 11.3 for males, corresponding to a mean total length of 57.6, 60.5 and $54.8 \mathrm{~mm}$, respectively. There were no statistically significant differences in mean lengths between creeks $\left(\mathrm{F}_{1}=2.37, \mathrm{P}>0.05\right)$, seasons $\left(\mathrm{F}_{1}=\mathrm{S} 1.5\right.$, $p>0.05)$ or sampling sites $\left(F_{3}=0.66 ; p>0.05\right)$. Females were significantly larger than males $\left(\mathrm{F}_{1}=38.42 ; \mathrm{p}<0.01\right)$.

The proportion of males to females was statistically different from that expected (1:1). A greater number of males occurred in sites near the mouth of the creeks in March and a greater number of females occurred in sites near the headwaters in September (Table 2).

Among the total number of $M$. amazonicum caught, the gonad maturation stage was determined for 990 specimens. The difference in the number of female individuals per maturation stage was only statistically significant for mature individuals in September, when such individuals were more abundant $\left(\mathrm{F}_{1}=11.86 ; \mathrm{p}<0.01\right)$. Visually, the frequency of the maturation stages indicates that females in all stages of development occurred in both seasons. However, Stages I (immature) and II (maturing) occurred more in the dry season (September). Stages III (mature), IV (with eggs adhered to pleopods) and V (spawned)

Table 1. Number of specimens caught, carapace length (Lcr, mm), body weight (W, g), minimum, maximum, mean and quartile (Q, 75 and 25\%) values by sex in Macrobrachium amazonicum collected from Combu and Tamanduaquara Creeks in September 2006 and March 2007.

\begin{tabular}{|c|c|c|c|c|c|}
\hline \multirow{2}{*}{ Sex } & & \multicolumn{2}{|c|}{ September } & \multicolumn{2}{|c|}{ March } \\
\hline & & Ler & $\mathbf{W}(\mathrm{g})$ & Lcr & W (g) \\
\hline \multirow{6}{*}{$q$} & $\mathrm{~N}$ & \multicolumn{2}{|c|}{472} & \multicolumn{2}{|c|}{30} \\
\hline & Min & 4.22 & 0.04 & 6.73 & 0.3 \\
\hline & Max & 29.00 & 36.7 & 18.17 & 3.54 \\
\hline & Mean & 12.31 & 2.86 & 11.86 & 1.94 \\
\hline & $75 \% \mathrm{Q}$ & 14.21 & 2.1 & 14.72 & 2.67 \\
\hline & $25 \% \mathrm{Q}$ & 9.88 & 0.81 & 8.86 & 0.82 \\
\hline \multirow{6}{*}{$\hat{0}$} & $\mathrm{~N}$ & & 458 & & 56 \\
\hline & Min & 6.33 & 0.13 & 6.53 & 0.4 \\
\hline & Max & 28.23 & 15.14 & 18.25 & 3.61 \\
\hline & Mean & 10.81 & 1.18 & 11.34 & 1.37 \\
\hline & $75 \% \mathrm{Q}$ & 11.65 & 0.66 & 12.7 & 1.78 \\
\hline & $25 \% \mathrm{Q}$ & 9.12 & 1.28 & 10.08 & 0.92 \\
\hline
\end{tabular}

Table 2. Number of male (M) and female (F) Amazon river shrimps caught at sampling sites in Guajará Bay (pooled sites) in September 2006 and March 2007.

\begin{tabular}{|c|c|c|c|c|c|}
\hline Month & Site & $\mathbf{F}$ & $\mathbf{M}$ & $+:_{0} \hat{0}$ & $\chi^{2}$ \\
\hline \multirow[t]{4}{*}{ March } & 1 & 14 & 30 & $1: 2$ & $5.82 *$ \\
\hline & 2 & 3 & 13 & $1: 4$ & $6.25^{*}$ \\
\hline & 3 & 3 & 9 & $1: 3$ & 3.00 \\
\hline & 4 & 10 & 9 & $1: 0.9$ & 0.05 \\
\hline \multirow[t]{4}{*}{ September } & 1 & 224 & 234 & $1: 1.04$ & 0.22 \\
\hline & 2 & 131 & 117 & $1: 0.8$ & 0.79 \\
\hline & 3 & 62 & 71 & $1: 1.2$ & 0.61 \\
\hline & 4 & 55 & 36 & 1:0.6 & 3.97* \\
\hline
\end{tabular}

$\mathrm{c}^{2}$ values with asterisk are statistically different at $5 \%$ level. 
were proportionally better represented in the rainy season (March). Males were found in the mature stage in both seasons, with a statistically significant difference only regarding the abundance of mature specimens, which was greater in September $\left(\mathrm{F}_{1}=8.182 ; \mathrm{p}<0.05\right)$ (Figure 3). Based on the occurrence of female maturation stages, the results demonstrate that, despite the apparent greater reproductive intensity in the rainy season, spawning occurs in both seasons.

Pooling the data from both seasons, Figure 4 illustrates the distribution of female maturation stages from the mouth to the headwaters of the creeks. The sites farthest from the mouth had a greater abundance of individuals in advances stages of maturation or spawned. For males, this tendency was observed in the dry season. Males in both maturation stages were found in all four sites of the creeks during the local high tide (Figure 5).

\section{Discussion}

The abundance of $M$. amazonicum was evident in the catches performed in the present study in small tidal creeks of Guajará Bay, demonstrating that this type of environment is favourable to the species. Based on the official data from
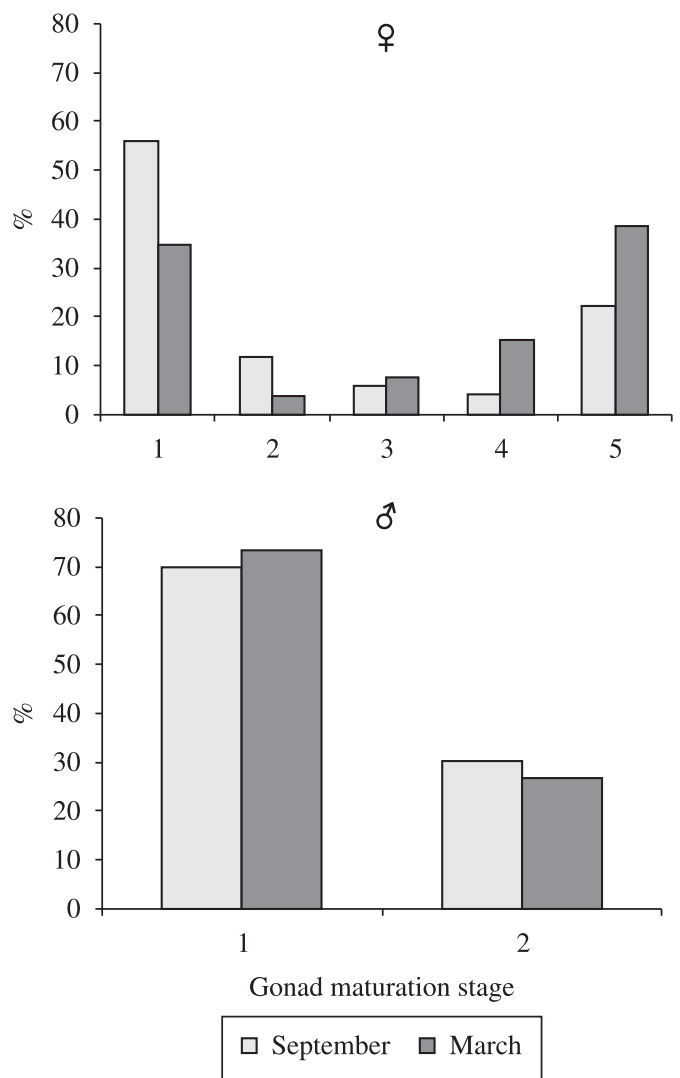

Figure 3. Relative percentage of number of M. amazonicum females and males per gonad maturation stage in Combu and Tamanduaquara Creeks in September 2006 and March 2007 in Guajará Bay. the Brazilian environmental agency (IBAMA, 2007) on the volume of shrimps landed by fisheries targeting crustaceans alone (124 t), the Amazon River shrimp is one of the most abundant resources in Amazonian rivers (Odinetz-Collart, 1987; Moraes-Riodades et al. 1999). However, there has been a reduction in the availability of this resource in Guajará Bay, perhaps due to a lack of management measures (Silva et al., 2006). Its wide distribution in both creeks and large rivers with strong outflow and its considerable tolerance to different environmental conditions, including brackish water, indicate that the species has a tremendous adaptation capacity (Araújo and Valenti, 2007; OdinetzCollart, 1991), which makes it suitable for extensive farming (Moraes-Riodades et al., 1999).

This abundance may be associated to the greater availability of food sources in Guajará Bay, as the Macrobrachium spp. and Potimirim are predatory and based on algae (Brito et al., 2006) and small tidal creeks accumulate a large amount of detritus (Peres, 1999) and high primary productive (Ribeiro et al., 1988; Paiva et al., 2006). Thus, the increase in abundance at sites farther from the mouth of the creek could be understood as a consequence of the large amount of sediment carried by the rivers of the Amazon region, which are then transported by the high tide and accumulate in the headwaters of these creeks. Moreover, the more internal sites of the creeks may offer greater opportunities for refuge from predation. Predators of M. amazonicum, such as adult Plagioscion squamossisimus (Bennemann et al., 2006) and Ageneiosus ucayalensis (Mérona et al., 2001), would have greater difficulty reaching the innermost portions of the creeks due to the shallow depths and large amount of vegetation debris on the bottom. Thus, the innermost sites offer greater protection to M. amazonicum, particularly during breeding periods.

Production stemming from the surrounding forest, which is deposited in the waters and on the bottom of tidal creeks, offers a large diversity of habitats and important sources of food for the numerous aquatic species that inhabit these ecosystems. In turn, aquatic macroinvertebrates, such as $M$. amazonicum, are the main organisms responsible for transforming organic particulate matter into smaller particles, which gives these organisms the denomination of shredders (Merrit and Lawson, 1992). Through the process of decomposition - metabolic breaking down of organic matter into simple organic and inorganic compounds and subsequent release of energy -, the material becomes available for use by different biological communities. Thus, the catches at sites farther from the mouth of the creeks in the present study may have been more productive because these environments provide greater efficiency with regard to the vital processes of the species, such as feeding, breeding and refuge from predators.

The presence of the Amazon River shrimp in the creeks sampled was constant throughout the year. The greater number of individuals caught in the drier season may be related to a greater ease in catching specimens with the same fishing effort. However, the gradational 

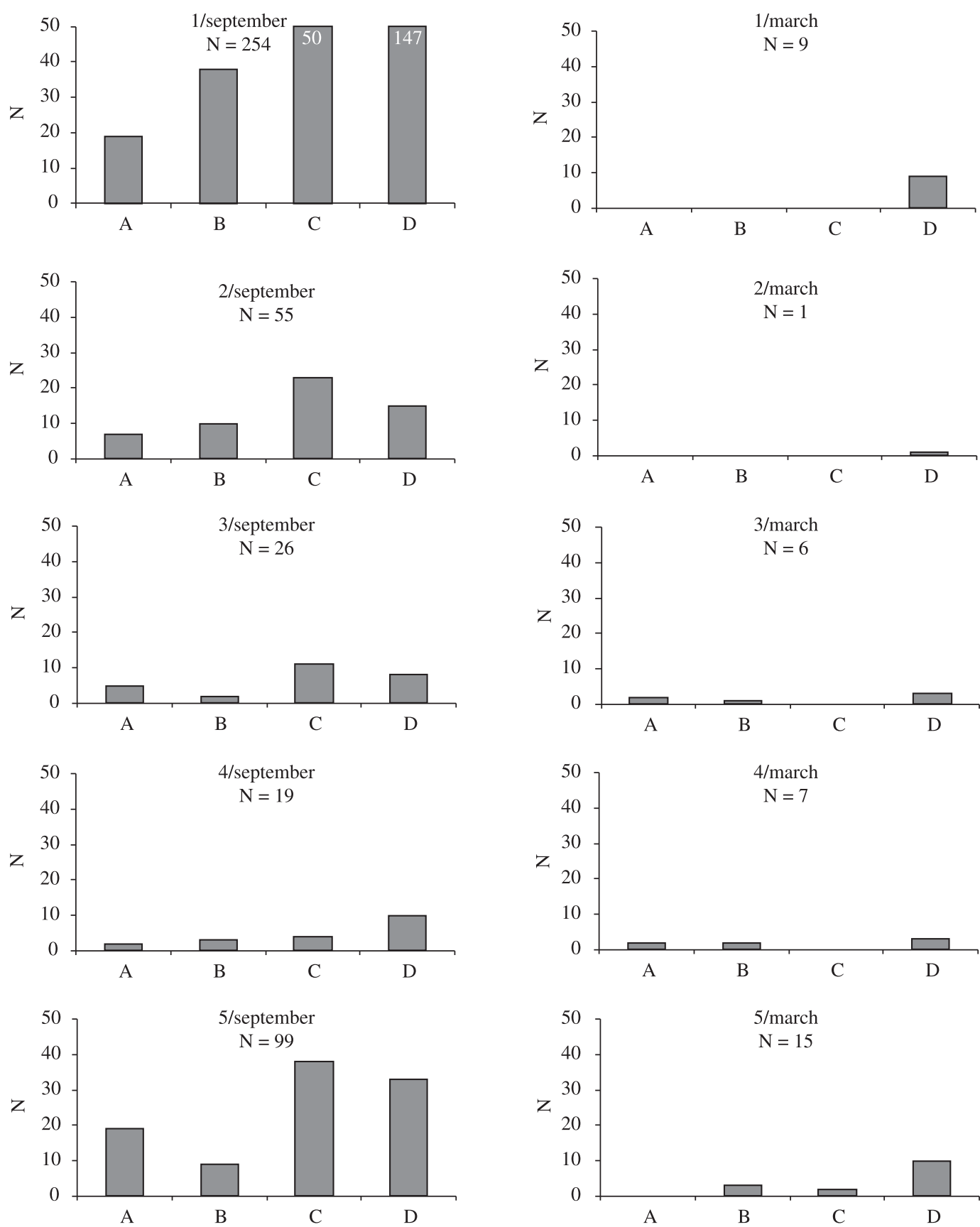

Figure 4. Frequency of occurrence of $M$. amazonicum female gonad maturation stages (I, II, III, IV and V) at four sampling sites (A, B, C and D) in Combu and Tamanduaquara Creeks in September 2006 and March 2007; abundance represented on different scales.

reduction in areas of refuge and the slight increase in water temperature and salinity in the dry season directly affect the composition and abundance of species of river shrimp (Welcomme, 1985).

The mean size of the specimens in the present study $(5.5 \mathrm{~cm}$ for females, $5.7 \mathrm{~cm}$ for males and $6 \mathrm{~cm}$ for sexes pooled) was similar to that reported by Silva (2006) for catches performed in the Guamá River on the margins of Combu Island $(6.3 \mathrm{~cm}$ for sexes pooled, $6.5 \mathrm{~cm}$ for females and $6 \mathrm{~cm}$ for males) and in the Guajará-Mirim River in the municipality of Vigia (Pará, Brazil) $(7.2 \mathrm{~cm}$ for males, $7.75 \mathrm{~cm}$ for females and $7.5 \mathrm{~cm}$ for sexed pooled) (Silva, 2002). According to Valenti (1987), Silva (2002) and Flexa et al. (2005), male adult freshwater shrimps of the genus Macrobrachium generally reach larger sizes than females. In the present study, however, the females had a larger mean carapace length, even though the largest individual was a male. According to Silva (2006), males 

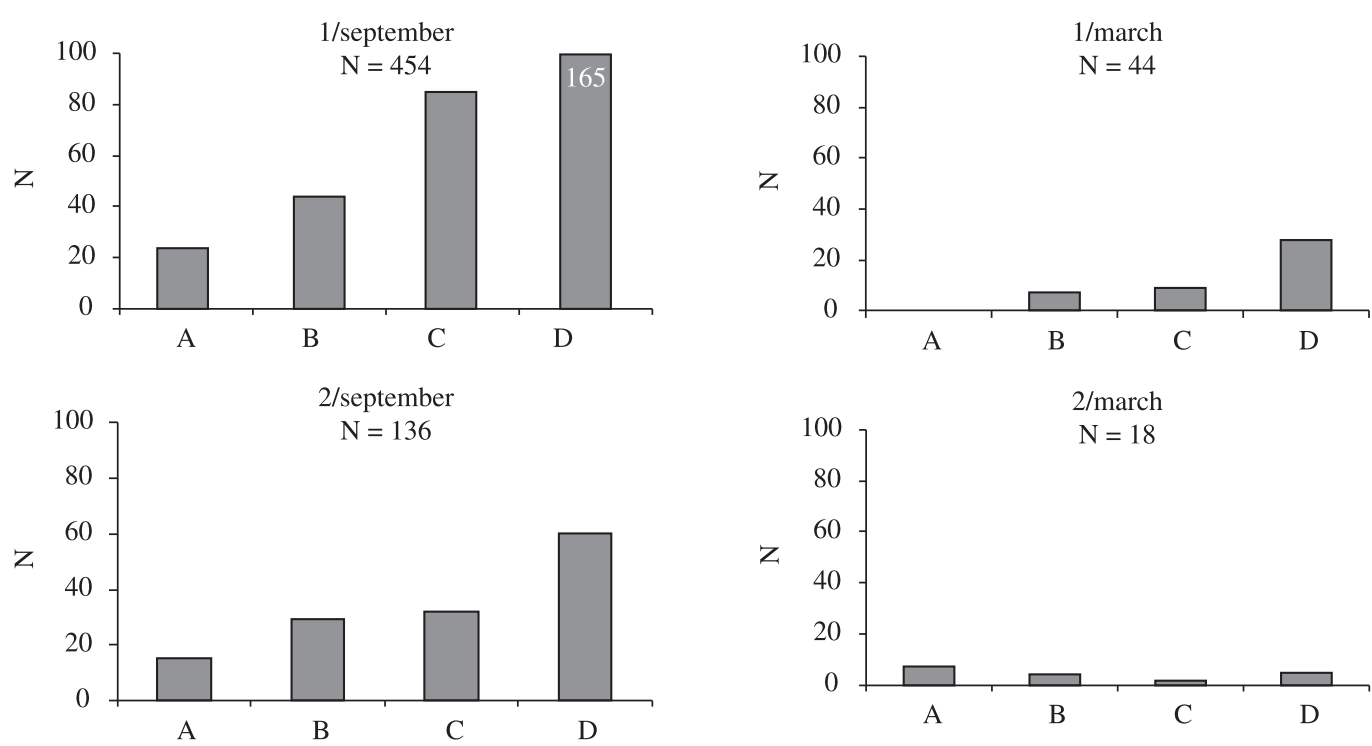

Figure 5. Frequency of occurrence of $M$. amazonicum male gonad maturation stages (I and II) at four sampling sites (A, B, $\mathrm{C}$ and D) in Combu and Tamanduaquara Creeks in September 2006 and March 2007; abundance represented on different scales.

that reach larger total lengths than females are caught with greater frequency, whereas the less aggressive females likely seek more protected areas. Thus, the largest individuals are removed in greater numbers, with smaller individuals remaining for recruitment.

Coelho and Santos (1993) have suggested that the number of specimens caught and their male to female proportions in a particular area of occurrence are likely related to the phases of the reproductive process; females aggregate in breeding grounds and are therefore more subject to capture when fishing is carried out in such areas. The present study corroborates this pattern, as the proportion of females to males in areas farthest from the mouth of the creeks was greater than 1:1. Borges (2003), Silva (2002) and Montoya (2003) recorded proportions of $1 \delta^{\top}: 3.36$, $2.4{ }^{\lambda}: 1+$ and $1 \delta^{\lambda}: 2$, respectively, for M. amazonicum in catches on riverbeds.

Regarding ovigerous females, the smallest specimen was caught on Combu Island and had a total length of $3.35 \mathrm{~cm}$ (extrapolating the Lcr measurement of $7.9 \mathrm{~mm}$ ), which is close to the length described by Silva (2002) in the municipality of Vigia $(\mathrm{Lt}=2.5 \mathrm{~cm})$, but smaller than that reported by Silva (2006) in larger creeks on Combu Island $(5.2 \mathrm{~cm})$. These results suggest that tidal creeks are favorable to breeding and attract females of all sizes.

According to Valenti (1984), river shrimps of the genus Macrobrachium have continuous or periodic reproduction and a long breeding season is also common (with a number of months in which spawning is more intensive) (Valenti et al., 1986). Studies on the reproductive intensity of Macrobrachium amazonicum in Guajará Bay are scarce. One exception is the study by Silva et al. (2006), who found that the species did not exhibit displacement of the position of the modes or mean length of the individuals caught throughout the year, likely due to continuous reproduction, which promotes the continuous entrance of recruits in the population.

The existence of a reproductive peak in some species of the genus Macrobrachium is evident in the hottest season of the year in locations with temperate climates, as described by Valenti et al. (1986), Dugan and Frakes (1972) and Dugan et al. (1975). No reproductive peak was found in the present study, probably due to the more stable climate in tropical environments. Although there was a greater proportion of females in Stages IV (with eggs adhered to the pleopods) and V (spawned) in the rainy season (March), females in Stages III (mature), IV (with eggs) and $\mathrm{V}$ (spawned) also occurred in high numbers in the drier season (September).

In several species of decapod crustaceans, gonad maturation and egg laying are not controlled only by endogenous mechanisms and are strongly related to favorable conditions, such as the availability of food sources (Shokita, 1973; Walker and Ferreira, 1985; Magalhães and Walker, 1988; Wong, 1989). This is particularly evident when species with seasonal reproduction patterns are submitted to controlled laboratory conditions and spawn throughout the year (Carvalho, 1978). Thus, it appears that the tidal creeks of Guajará Bay offer favourable breeding conditions in both the rainy and drier season.

In a study on the same species in the Central Amazon, Odinetz-Collart (1991) found that two factors favor gonad development: water current speed and primary production. This particularity also seems to explain the number of individuals - many of which were ready for breeding found in the tidal creeks, where there is high productivity and slow currents. 
The lesser abundance of ovigerous females in many studies involving catches carried out on riverbeds in the Amazon region underscores the finding that breeding individuals prefer more protected areas, such as small branches of rivers and creeks, where the incubation of the eggs and, consequently, reproductive success are better ensured (Ismael and New, 2000). This may also explain the greater proportion of males at the mouths of the creeks and females in the headwaters.

Considering the rapid growth in human populations and the process of urbanisation on the banks of these bodies of water due to their proximity to the city of Belém, which is the largest metropolis in the region (more than one million inhabitants), there is a need for conservation measures directed at small tidal creeks and streams, such as those studied in the present investigation. This exponential population growth contributes toward the degradation of water quality, the deforestation of river banks and a reduction in environments that are favourable to the reproductive success of $M$. amazonicum as well as other species of shrimps and aquatic resources found in these ecosystems (Torres, 2010).

Acknowledgements - The authors are grateful to the researchers Roberto V. Espírito-Santo M. Sc., Antônio Sérgio Carvalho M. Sc., Priscila Amorim Carmona, M.Sc., Allan Jameson Silva de Jesus M.Sc., Charles Michel Oliveira, Leocyvan Nunes, Gilberto Meireles and scholars João Segundo, Renata, Beatriz and Emílio Bentes for assistance in the sampling, transport and sorting of the biological material; to the fishermen Mr. João Rosa ('Parau') and Marinaldo; and to the Brazilian Funding agency Conselho Nacional de Pesquisa e Desenvolvimento Científico e Tecnológico for funding this study (process $\mathrm{n}^{\mathrm{o}}$ 553125/2005-2) and awarding the first author a doctoral grant. All procedures were conducted with authorisation from the Brazilian environmental agency (Protocol IBAMA/MMA $\left.n^{\circ} 02018.00729 / 06-36\right)$.

\section{References}

ARAÚJO,MC. and VALENTI, WC., 2007. Feeding habit of the Amazon River prawn Macrobrachium amazonicum larvae. Aquaculture, no. 265, p. 187-193

Agência Nacional das Águas - ANA. Brasília. Available from: $<$ http://www.ana.gov.br>. Acessed In 3 dez. 2007.

BENNEMANN, ST., CAPRA, LG., GALVES, W. and SHIBATTA, OA., 2006. Dinâmica trófica de Plagioscion squamosissimus (Perciformes, Sciaenidae) em trechos de influência da represa Capivara (rios Paranapanema e Tibagi). Iheringia, Série Zoologia, no. 96 , p. 115-119.

BORGES, MS., 2003. Distribuição, abundância e biologia reprodutiva de Macrobrachium amazonicum (Heller, 1862) $e$ Macrobrachium jelskii (Miers, 1877) (Crustacea, Decapoda, Palaemonidae) no Açude de Público de Rômulo Campos, Itiúba - Bahia. Salvador: Universidade Federal da Bahia. Monografia de Graduação.

BRITO, EF., MOULTON, TP., SOUZA, ML. and BUNN, SE. 2006. Stable isotope analysis indicates microalgae as the predominant food source of fauna in a coastal forest stream, south-east Brazil. Austral Ecology, no. 31, p. 623-63.
CARVALHO, HA., 1978. Ciclo sexual de Macrobrachium acanthurus (Wiegmann, 1836) (Crustacea, Decapoda): relações com fatores abióticos e ciclo de intermudas. São Paulo: Instituto de Biociências da Universidade de São Paulo. Tese de Doutorado.

CARVALHO, HAC. and PEREIRA, MCG., 1981. descrição dos estágios ovarianos de Macrobrachium acanthurus (Wiegmann, 1836) (Crustacea, Palaemonidae) durante o ciclo reprodutivo. Ciência e Cultura, vol. 33, no. 10, p. 1353-1359.

CHAVES, PTC. and MAGALHÃES, C., 1983. O desenvolvimento ovocitário em Macrobrachium amazonicum (Heller, 1862) (Crustacea: Decapoda: Palaemonidae), camarão dulcícola da região Amazônica. Acta Amazonica, vol. 23, no. 1, p. 17-23.

COELHO, PA. and SANTOS, MCF., 1993. Época da reprodução do camarão rosa, Penaeus subtilis, Pérez-Farfante, 1967 (Crustacea, Decapoda, Penaeidae) na região de Tamandaré, PE. Boletim Técnico-Científico do CEPENE, vol. 1, no. 1, p. 57-72.

CORDEIRO, CA., 1987. Estudo da salinização do estuário do Rio Pará no trecho Belém - Mosqueiro. Belém: Universidade Federal do Pará. Dissertação de Mestrado em Geologia e Geoquímica.

DUGAN, CC. and FRAQUES, TA., 1972. Culture of brackishfreshwater shrimp Macrobrachium acanthurus, M. carcinus and M. ohione. World Mariculture Society. 7 p.

DUGAN, CC., HAGOOD, RW., and FRAKES, TA., 1975. Development of spawning and mass larval rearing techniques for brackish-freshwater shrimps of the genus Macrobrachium (Decapoda, Palaemonidae). Florida Marine Research Publication, vol. 12, p. 1-28.

FLEXA, CE., SILVA, KCA., ARNAUD, J., CINTRA, IHA., and PORTO, VM., 2005. Morfometria do camarão-cascudo Macrobrachium amazonicum (Heller, 1862) no município de Cametá/Pará. In Anais do 14nd Congresso Brasileiro de Engenharia de Pesca, 2005. Fortaleza: FAEP/BR.

Instituto Brasileiro do Meio Ambiente e dos Recursos Naturais Renováveis - IBAMA, 2007. Estatística da Pesca 2005. Brasília: IBAMA. Available from: <www.ibama.gov.br/recursos_pesqueiros>.

ISMAEL, D. and NEW, MB., 2000, Biology. In NEW, MB. and VALENTI, WC. (Eds.). Freshwater prawn culture. Oxford: Blackwell. p. 18-40.

MAGALHÃES, C. 1985. Desenvolvimento larval obtido em laboratório de palaemonídeos da região amazônica. I Macrobrachium amazonicum (Heller, 1862) (Crustacea, Decapoda). Amazoniana, vol. 9, no. 2, p. 247-274.

MAGALHÃES, C. and WALKER, I., 1988. Larval development and ecological distribution of Central Amazonian palaemonid shrimps (Decapoda, Caridea). Crustaceana, no. 55, p. 279-292.

MÉRONA, B., SANTOS, GM., and ALMEIDA, RG., 2001. Short term effects of Tucuruí Dam (Amazonia, Brazil) on the trophic organization of fish communities. Environmental biology of fishes, no. 60, p. 375-392.

MERRIT, RW. and LAWSON, DL., 1992. The role of leaf litter macroinvertebrates in stream - floodplain dynamics. Hydrobiologia, no. 248 , p. $65-77$.

MONTEIRO, MDR., MELO, NFAC., ALVES, MAMS. and PAIVA, RS. 2009. Composição e distribuição do microfitoplâncton do Rio Guamá no trecho entre Belém e São Miguel do Guamá, Pará, Brasil. Boletim do Museu Paraense Emílio Goeldi - Ciências naturais, vol. 4, no. 3, p. 341-351. 
MONTOYA, JV., 2003. Freshwater shrimps of the genus Macrobrachium associated with roots of Eichhornia crassipes (Water Hyacinth) in the Orinoco Delta (Venezuela). Caribbean Journal of Science, vol. 39, no. 1, p. 155-159.

MORAES-RIODADES, PMC., VALENTI, WC., PERALTA, ASL. and AMORIN, MDL., 1999. Carcinicultura de água doce no estado do Pará: situação e perspectivas. In Anais do 11nd Congresso Brasileiro de Engenharia de Pesca, 1999. Recife.

MORAES-RIODADES, PC. and VALENTI, WC., 2004. Morphotypes in male Amazon River prawns, Macrobrachium amazonicum. Aquaculture, no. 236, p. 297-307.

MOREIRA, E., 1966. Belém e sua expressão geográfica. Belém: Imprensa Universitária.

MOREIRA, LC. and ODINETZ-COLLART, O., 1993. Migração vertical nictemeral das larvas de Macrobrachium amazonicum num lago de várzea da Amazônia Central, Ilha do Coreiro, Brasil. Amazoniana, vol 12, no. 3-4, p. 385-398.

NEW, MB., 1980. El potential del cultivo de Macrobrachium en Latinoamerica. Revista Latinoamericana de Acuicultura, vol. 6, no. 1, p. 25-37.

ODINETZ-COLLART, O., 1987. La pêche crevettière de Macrobrachium amazonicum (Palaemonidae) dans le Bas-Tocantins après la fermeture du barrage de Tucuruí (Brésil). Revista de Hidrobiologia Tropical, vol. 20, no. 2, p. 131-144.

-, 1991. Strategie de reproduction de Macrobrachium amazonicum em Amazonie Centrale (Decapoda, Caridae, Palaemonidae). Crustaceana, vol. 61, no. 3, p. 253-270. http://dx.doi. org/10.1163/156854091X00146

ODINETZ-COLLART, O. and MAGALHÃES, C., 1994. Ecological constraints and life history strategies of palaemonid prawns in Amazonia. Verhandlungen Internationalen Vereinigung fur Theoretische und Angewandte Limnologie, no. 25, p. 2460-2467.

ODINETZ-COLLART, O. and MOREIRA, LC., 1993. Migração vertical nictemeral das larvas de Macrobrachium amazonicum num lago de várzea na Amazônia Central, Ilha do Careiro, Brasil. Amazoniana, vol. 3, no. 4, p. 385-389.

PAIVA, RS., ESKINAZI-LEÇA, E., PASSAVANTE, JZO., SILVA-CUNHA, MGG. and MELO, NFAC. 2006. Considerações ecológicas sobre o fitoplâncton da Baía do Guajará e foz do Rio Guamá, Pará, Brasil. Boletim do Museu Paraense Emílio Goeldi - Ciências naturais, vol. 1, no. 2, p. 133-146.

PERES, AC., 1999. A comunidade zooplanctônica em um canal de maré, no estuário do rio Caeté, município de Bragança, Pará, Brasil. Belém: Universidade Federal do Pará. Dissertação de Mestrado em Ecologia.

RIBEIRO-FILHO, JBG., 1988. Aspectos do aparelho reprodutivo do camarão pitú, Macrobrachium carcinus (Linnaeus). Fortaleza: Universidade Federal do Ceará. Monogradia de Graduação.

RODRÍGUEZ, G., 1982. Fresh-water shrimps (Crustacea, Decapoda, Natantia) of the Orinoco basin and the Venezuelan Guayana. Journal of Crustacean Biology, no. 2, p. 378-391.

ROMERO, ME., 1982. Preliminary observation on potential of culture of Macrobrachium amazonicum in Venezuela. In NEW, MB. (Ed.). Giant prawn farming. Elsevier: Amsterdam. p. 411-416.

SAMPAIO, CMS., SILVA, RR., SANTOS, JA. and SALES, SP., 2007. Reproductive cycle of Macrobrachium amazonicum females (Crustacea, Palaemonidae). Brazilian Journal of Biology, vol. 67 , no. 3 , p. 551-559. http://dx.doi.org/10.1590/S151969842007000300022

SAMPAIO, CMS., SOARES-FILHO, AA., ARAÚJO-NETO, M P., FEITOSA, LS., SILVA, LP. and CHAVES, EC., 2008. Conteúdo do trato digestório de Macrobrachium amazonicum (Crustacea, Palaemonidae) capturado em ambiente natural. In Abstracts of Aquaciência, 2008. Maringá.

SANTOS, JA., SAMPAIO, CMS. and SOARES-FILHO, AA., 2006. Male population structure of the Amazon river prawn (Macrobrachium amazonicum) in a natural environment. Nauplius, vol. 14, no. 2, p. 55-63.

SHOKITA, S., 1973. Abbreviated larval development of the fresh-water prawn Macrobrachium shokitai Fujino et Baba (Decapoda, Palaemonidae) from Iriomote Island of the Ryukyus. Annotationes Zooogicae. Japonenses, vol. 46, no. 2, p. 111-126.

SILVA, KCA., 2002. Aspectos da bioecologia do camarão cascudo, Macrobrachium amazonicum Heller, 1962 (Crustacea, Decapoda, Palaemonidae) no município de Vigia-Pará-Brasil. Belém: Universidade Federal do Pará. Dissertação de Mestrado em Ciência Animal.

SILVA, KCA., SOUZA, RAL. and CINTRA, IHA., 2002. Espécies de camarões capturadas em áreas estuarinas no município de Vigia-Pará-Brasil. Boletim Técnico-Científico do CEPNOR, vol. 2, no. 1, p. 81-96.

SILVA, MN., 2006. Dinâmica populacional do camarão cascudo Macrobrachium amazonicum (Heller, 1862). Belém: Universidade Federal do Pará. Dissertação de Mestrado em Ciência Animal.

SILVA, MN., FRÉDOU, FL. and ROSA-FILHO, JS., 2007. Estudo do crescimento do camarão Macrobrachium amazonicum (Heller, 1863) da Ilha de Combu, Belém, Estado do Pará. Amazônia, Ciência \& Desenvolvimento, vol. 2, no. 4, p. 85-104.

TORRES, DG., 2010. A comunidade íctica e a atividade pesqueira em uma ilha do complexo estuarino amazônico, Ilha das Onças - Barcarena - Pará. Belém: Universidade Federal do Pará. Dissertação de Mestrado.

VALENTI, WC., 1984. Estudo populacional dos camarões de água doce Macrobrachium acanthurus (Wiegmann, 1836) $e$ Macrobrachium carcinus (Linnaeus, 1758) do Rio Ribeira de Iguape (Crustacea, Palaemonidae). São Paulo: Universidade de São Paulo. Dissertação de Mestrado.

VALENTI, W., 1987. Comportamento reprodutivo de camarões de água doce. Anais de ecologia, no. 5, p. 195-202.

VALENTI, WC., MELLO, JTC. and LOBÃO, VL., 1986. Dinâmica da reprodução de Macrobrachium acanthurus (Wiegmann, 1836) e Macrobrachium carcinus (Linnaeus, 1758) do Rio Ribeira de Iguape (Crustacea, Decapoda, Palaemonidae). Ciência e Cultura, vol. 38, no. 7, p. 1256-1262.

-, 1989. Fecundidade em Macrobrachium acanthurus (Wiegmann, 1836) do Rio Ribeira do Iguape (Crustacea, Decapoda, Palaemonidae). Revista Brasileira de Zoologia, vol 6, no. 1, p. 9-15.

VIANA, AP., FRÉDOU, FL., FRÉDOU, T., TORRES, MF. and BORDALO, A., 2010. Fish fauna as an indicator of environmental quality in an urbanised region of the Amazon Estuary. Journal of Fish Biology, no. 76, p. 467-486.

VIEIRA, IM., 2003. Bioecologia e pesca do camarão, Macrobrachium amazonicum (Heller, 1862) no Rio Amazonas, $A P$. Brasília: Universidade de Brasília. Dissertação de Mestrado em Desenvolvimento Sustentável. 
WALKER, I. and FERREIRA, MJN., 1985. On the population dynamics and ecology of the shrimp species (Crustacea, Decapoda, Natantia) in the Central Amazonian river Tarumã-Mirim. Oecologia, no. 66 , p. $264-270$.

WELCOMME, RL., 1985. River fisheries. FAO Fisheries Technical, no. 262 , p. $1-330$.
WONG, JT.Y. 1989. Abbreviated larval development of Macrobrachium hainanense (Parisi 1919) reared in laboratory (Decapoda, Caridea, Palaemonidae). Crustaceana, vol. 56, no. 1, p.18-30.

ZAR, JH. 1996. Bioestatistical analysis. Upper Saddle River: Prentice Hall. 
